\title{
Taxonomy of Marine Pseudomonas Species: P. stanieri sp. nov.; P. perfectomarina sp. nov., nom. rev.; P. nautica; and P. doudoroffii
}

\author{
PAUL BAUMANN, ${ }^{1 *}$ RON D. BOWDITCH, ${ }^{1}$ LINDA BAUMANN, ${ }^{1}$ AND BLAINE BEAMAN ${ }^{2}$ \\ Department of Bacteriology, University of California, ${ }^{\prime}$ and Department of Medical Microbiology, University \\ of California Medical School, ${ }^{2}$ Davis, California 95616
}

Recent studies of the evolutionary relationships of nonfermentative, gramnegative, rod-shaped, polarly flagellated, marine bacteria have indicated that some are members of the lineage which includes the type species of the genus Pseudomonas, Pseudomonas aeruginosa. As a result of these findings, one species equivalent (group G-1) with a guanine plus cytosine content slightly beyond the lower limit proposed for Pseudomonas is now included in this genus under the designation Pseudomonas stanieri sp. nov. (type strain $146=$ ATCC 27130). In addition, "Pseudomonas perfectomarinus," an organism not included in the Approved List of Bacterial Names, is a recognizable species and part of this lineage. This name has, therefore, been revived and corrected to Pseudomonas perfectomarina sp. nov., nom. rev. (type strain $218=$ ATCC 14405). The phenotypes of these two species and their type strains are described along with those for two other marine Pseudomonas, Pseudomonas nautica and Pseudomonas doudoroffii.

In our study of obligately respiratory, gramnegative bacteria of marine origin, a number of clusters of phenotypically related strains were not given species designations since they could not at that time be readily accommodated into existing genera (3). One such cluster, group G-1, consisted of polarly flagellated, rod-shaped organisms with guanine plus cytosine $(\mathrm{G}+\mathrm{C})$ contents in their deoxyribonucleic acids (DNAs) of 55 to $57 \mathrm{~mol} \%$, somewhat below the accepted $\mathrm{G}+\mathrm{C}$ range of the genus Pseudomonas 58 to 70 mol\%) (20). Recent studies of the evolutionary relationships of these organisms, employing an immunological technique for measuring sequence similarities of Fe-containing superoxide dismutases and glutamine synthetases, have shown that these organisms are related to Pseudomonas aeruginosa as well as the marine species Pseudomonas doudoroffii, Pseudomonas nautica, and "Pseudomonas perfectomarinus" (E. F. DeLong, L. Baumann, R. D. Bowditch, and P. Baumann, Arch. Microbiol., in press). The latter species is not on the Approved List of Bacterial Names (17). In this publication, we propose to place the strains of group G-1 into Pseudomonas stanieri sp. nov., revive the corrected name Pseudomonas perfectomarina sp. nov., nom. rev., and provide a description of the phenotypic properties of these species as well as $P$. nautica and $P$. doudoroffii.

\section{MATERIALS AND METHODS}

The sources of the strains used in this study as well as the methods used for their isolation have been described (3). Detailed protocols of the methods used for the phenotypic characterization of the strains have been previously published (6).

\section{RESULTS}

All of the strains were polarly flagellated, straight rods which were able to utilize acetate, DL-lactate, or pyruvate as sole sources of carbon and energy. All were oxidase positive and required $\mathrm{Na}^{+}$or seawater for growth. None was able to grow at $4^{\circ} \mathrm{C}$, utilize $\mathrm{H}_{2}$ as an energy source and $\mathrm{CO}_{2}$ as the carbon source, or produce an extracellular alginase or chitinase. None had an arginine dihydrolase system. The following compounds were not utilized by any of the strains: D-xylose, D-arabinose, L-arabinose, Dfucose, L-rhamnose, D-mannose, D-galactose, sucrose, trehalose, cellobiose, melibiose, lactose, inulin, salicin, cellulose, gluconate, mucate, galacturonate, $\mathrm{N}$-acetylglucosamine, formate, oxalate, maleate, $\mathrm{D}-(-)$-tartrate, mesotartrate, citraconate, mesaconate, mannitol, sorbitol, meso-inositol, adonitol, methanol, isopropanol, geraniol, $o$-hydroxybenzoate, phenylethanediol, phenol, naphthalene, L-norleucine, L-lysine, L-citrulline, DL- $\gamma$-aminobutyrate, DL- $\delta$ aminovalerate, anthranilate, $m$-aminobenzoate, 
TABLE 1. Phenotypic properties not universally present in marine species of Pseudomonas ${ }^{a}$

\begin{tabular}{|c|c|c|c|c|c|c|c|c|c|c|}
\hline \multirow[b]{2}{*}{ Trait } & \multicolumn{3}{|c|}{ P. stanieri } & \multirow{2}{*}{$\begin{array}{l}\text { P. perfectomarina } \\
\text { Phenotype of } \\
\text { strain } 218^{\mathrm{T}} \\
\text { (ATCC } 14405 \text { ) }\end{array}$} & \multicolumn{3}{|c|}{$P$. nautica } & \multicolumn{3}{|c|}{ P. doudoroffii } \\
\hline & $\begin{array}{l}\text { Pheno- } \\
\text { type of } \\
\text { species }\end{array}$ & $\begin{array}{l}\text { Phenotype of } \\
\text { strain } 146^{\mathrm{I}} \\
\text { (ATCC } \\
27130 \text { ) }\end{array}$ & $\begin{array}{l}\text { Strains which are } \\
\text { positive or negative" }\end{array}$ & & $\begin{array}{l}\text { Pheno- } \\
\text { type of } \\
\text { species }\end{array}$ & $\begin{array}{l}\text { Phenotype of } \\
\text { strain } 197^{1} \\
\text { (ATCC } \\
27132 \text { ) }\end{array}$ & $\begin{array}{l}\text { Strains which are } \\
\text { positive or negative }\end{array}$ & $\begin{array}{l}\text { Pheno- } \\
\text { type of } \\
\text { species }\end{array}$ & $\begin{array}{l}\text { Phenotype of } \\
\text { strain } 70^{\mathrm{F}} \\
\text { (ATCC } \\
27123 \text { ) }\end{array}$ & $\begin{array}{l}\text { Strains which are } \\
\text { positive or negative" }\end{array}$ \\
\hline $\begin{array}{l}\text { No. of polar fla- } \\
\text { gella }{ }^{c^{c}}\end{array}$ & 1 & 1 & & - & 1 & 1 & & $1-3$ & $1-3$ & \\
\hline Motility & + & + & & - & (32) & + & $(-): 191,192$ & + & + & \\
\hline $\begin{array}{l}\text { poly- } \beta \text {-hydroxy- } \\
\text { butyrate accu- } \\
\text { mulation }\end{array}$ & + & + & & - & - & - & & + & + & \\
\hline $\begin{array}{l}\text { Aromatic ring } \\
\text { cleavage }^{d}\end{array}$ & $m$ & $m$ & & - & $o$ & $o$ & & $o$ & $o$ & \\
\hline Denitrification & - & - & & + & (29) & + & $(-): 187-191$ & - & - & \\
\hline $\mathrm{NO}_{3}^{-} \rightarrow \mathrm{NO}_{2}^{-}$ & - & - & & - & 14 & - & $\begin{array}{l}(+): 161-165 \\
167,171,177 . \\
181-186,188- \\
190\end{array}$ & (8) & + & $(-): 67,68$ \\
\hline \multicolumn{11}{|l|}{ Growth at: } \\
\hline $40^{\circ} \mathrm{C}$ & 6 & + & $\begin{array}{l}(+): 145-147 \\
149.150 .152\end{array}$ & + & (29) & + & $(-): 189-192,194$ & + & + & \\
\hline $45^{\circ} \mathrm{C}$ & - & - & & - & 17 & + & $\begin{array}{l}(+): 165,167- \\
\quad 169.171,175- \\
\quad 186\end{array}$ & 3 & - & $(+): 72-75$ \\
\hline \multicolumn{11}{|l|}{ Production of: } \\
\hline Amylase & - & - & & + & 3 & - & $(+): 181-183$ & - & - & \\
\hline Gelatinase & - & - & & - & 1 & - & $(+): 188$ & - & - & \\
\hline Lipase & - & - & & - & + & + & & - & - & \\
\hline \multicolumn{11}{|l|}{ Utilization of: } \\
\hline D-Ribose & - & - & & - & - & - & & 4 & - & $(+): 73-76$ \\
\hline D-Glucose & - & - & & + & - & - & & - & - & \\
\hline D-Fructose & - & - & & - & - & - & & + & + & \\
\hline Maltose & - & - & & + & - & - & & - & - & \\
\hline Saccharate & - & - & & + & - & - & & - & - & \\
\hline Glucuronate & - & - & & + & - & - & & 2 & - & $(+): 68,76$ \\
\hline Propionate & + & + & & + & + & + & & 1 & - & $(+): 67$ \\
\hline Butyrate & + & + & & + & + & + & & - & - & \\
\hline Isobutyrate & + & + & & + & $(31)$ & + & $(-): 187,189,190$ & - & - & \\
\hline Valerate & 8 & + & $(-): 151,152,155$ & + & + & + & & - & - & \\
\hline Isovalerate & 6 & + & $(+): 145-150$ & + & 24 & + & $(-): 184-192,194$ & - & - & \\
\hline Caproate & 7 & + & $(+): 145-150,155$ & + & + & + & & - & - & \\
\hline Heptanoate & 1 & - & $(+): 155$ & + & + & + & & - & - & \\
\hline
\end{tabular}




\begin{tabular}{|c|c|c|c|}
\hline Caprylate & 1 & - & $(+): 155$ \\
\hline Pelargonate & 2 & - & $(+): 149,155$ \\
\hline Caprate & 6 & + & $(+): 145-149.155$ \\
\hline Malonate & - & - & \\
\hline $\begin{array}{l}\text { Succinate } \\
\text { Fumarate }\end{array}$ & $\begin{array}{l}+ \\
+\end{array}$ & $\begin{array}{l}+ \\
+\end{array}$ & \\
\hline Glutarate & 6 & + & $(+): 145-149.154$ \\
\hline Adipate & - & - & \\
\hline Pimelate & - & - & \\
\hline Suberate & - & - & \\
\hline Azelate & - & - & \\
\hline Sebacate & - & - & \\
\hline DL-Malate & 5 & + & $(+): 145-149$ \\
\hline L-(+)-Tartrate & 1 & - & $(+): 153$ \\
\hline $\begin{array}{l}\text { DL- } \beta- \\
\text { Hydroxybu- } \\
\text { tyrate }\end{array}$ & + & + & \\
\hline Glycolate & - & - & \\
\hline DL-Glycerate & - & - & \\
\hline Citrate & (9) & + & $(-): 150,152$ \\
\hline $\begin{array}{l}\alpha \text {-Ketoglutar- } \\
\text { ate }\end{array}$ & + & + & \\
\hline Aconitate & (10) & + & $(-): 150$ \\
\hline Laevulinate & - & - & \\
\hline Itaconate & 1 & - & $(+): 154$ \\
\hline $\begin{array}{l}\text { Mesaconate } \\
\text { Glycerol }\end{array}$ & $\begin{array}{l}- \\
-\end{array}$ & $\begin{array}{l}- \\
-\end{array}$ & \\
\hline $\begin{array}{l}\text { Ethylene gly- } \\
\text { col }\end{array}$ & - & - & \\
\hline $\begin{array}{l}\text { Propylene gly- } \\
\text { col }\end{array}$ & 6 & + & $(+): 145-150$ \\
\hline $\begin{array}{l}\text { 2,3-Butylene- } \\
\text { glycol }\end{array}$ & 8 & + & $(-): 149.152 .155$ \\
\hline Ethanol & + & + & \\
\hline n-Propanol & + & + & \\
\hline
\end{tabular}

$(-): 189,190$

(-): 163, 164, 189

(-): $174,175,194$

(-): $174,175,194$

(+): 194

$(+): 172,173$.

176-180, 191-

194

(+): 181-183.

$191,192,194$

(+): 191-194

$(+): 187,191-194$

$(+)$ : 181-183,

187, 191-194

(-): 170, 174,

189, 190,194

$(-): 174,175$

189,190

$\begin{array}{lccc} & (9) & + & (-): 68 \\ & (9) & + & (-): 68 \\ (+): 163-168, & + & + & \\ 170,171,176, & & & \\ 178-180 & & & \end{array}$

$(+): 187$

$(+): 172,173,191$

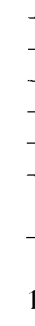

(+): 165-168,

171, 178-180

$(+): 163-164$

(-): 162,169 ,

181-186, 188-

190,194

(-): 181-186,

189. 190, 194
$(+): 67,74,75$

(+): 71-73, 75

(-): 68

$(+): 68,70,76$

$-): 68$

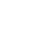

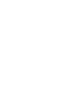

$\begin{array}{ll}+ & \\ - & \\ - & \\ - & \\ - & \\ - & \\ - & \\ - & (+): 67 \\ + & (-): 69 \\ & \\ - & (+): 67\end{array}$


TABLE 1-Continued

\begin{tabular}{|c|c|c|c|c|c|c|c|c|c|c|}
\hline \multirow[b]{2}{*}{ Trait } & \multicolumn{3}{|c|}{ P. stanieri } & \multicolumn{2}{|l|}{$P$. perfectomarina } & \multicolumn{2}{|c|}{ P. nautica } & \multicolumn{3}{|c|}{ P. doudoroffii } \\
\hline & $\begin{array}{l}\text { Pheno- } \\
\text { type of } \\
\text { species }\end{array}$ & $\begin{array}{l}\text { Phenotype of } \\
\text { strain } 146^{\mathrm{T}} \\
\text { (ATCC } \\
27130)\end{array}$ & $\begin{array}{l}\text { Strains which are } \\
\text { positive or negative }\end{array}$ & $\begin{array}{l}\text { Phenotype of } \\
\text { strain } 218^{\mathrm{T}} \\
\text { (ATCC } 14405 \text { ) }\end{array}$ & $\begin{array}{l}\text { Pheno- } \\
\text { type of } \\
\text { species }\end{array}$ & $\begin{array}{l}\text { Phenotype of } \\
\text { strain } 197^{1} \\
\text { (ATCC } \\
\text { 27132) }\end{array}$ & $\begin{array}{l}\text { Strains which are } \\
\text { positive or negative }\end{array}$ & $\begin{array}{l}\text { Pheno- } \\
\text { type of } \\
\text { species }\end{array}$ & $\begin{array}{l}\text { Phenotype of } \\
\text { strain 70 } \\
\text { (ATCC } \\
27123 \text { ) }\end{array}$ & $\begin{array}{l}\text { Strains which are } \\
\text { positive or negative }\end{array}$ \\
\hline$n$-Butanol & + & + & & + & 27 & + & $(-): 181-186,188$ & - & - & \\
\hline Isobutanol & + & + & & + & 19 & + & $(+): 162-180$ & - & - & \\
\hline D-Mandelate & 1 & - & $(+): 150$ & - & - & - & & - & - & \\
\hline L-Mandelate & 1 & - & $(+): 150$ & - & - & - & & - & - & \\
\hline $\begin{array}{l}\text { Benzoylfor- } \\
\text { mate }\end{array}$ & 1 & - & $(+): 150$ & - & - & - & & - & - & \\
\hline Benzoate & 5 & + & $\begin{array}{l}(+): 145,146 \\
150,153,154\end{array}$ & - & 13 & + & $\begin{array}{r}(+): 168,177- \\
186,191,192\end{array}$ & + & + & \\
\hline $\begin{array}{c}m \text {-Hydroxy- } \\
\text { benzoate }\end{array}$ & 7 & + & $\begin{array}{c}(+): 145,146 \\
149-153\end{array}$ & - & - & - & & - & - & \\
\hline $\begin{array}{c}p \text {-Hydroxy- } \\
\text { benzoate }\end{array}$ & 7 & + & $\begin{array}{c}(+): 145,146 \\
149-153\end{array}$ & - & - & - & & 4 & + & $(+): 67,68,70,72$ \\
\hline Phenylacetate & $(10)$ & + & $(-): 154$ & - & - & - & & - & - & \\
\hline Quinate & 5 & + & $\begin{array}{c}(+): 145,146 \\
149,153\end{array}$ & - & - & - & & - & - & \\
\hline Glycine & - & - & & - & - & - & & + & + & \\
\hline$L-\alpha$-Alanine & + & + & & + & 5 & - & $(+): 161-164,170$ & + & + & \\
\hline D- $\alpha$-Alanine & + & + & & + & 8 & + & $\begin{array}{l}(+): 161-164 \\
\quad 178,179,181 \\
\quad 186\end{array}$ & + & + & \\
\hline$\beta$-Alanine & 7 & + & $\begin{array}{c}(-): 149,150, \\
152,153\end{array}$ & - & - & - & & (9) & + & $(-): 68$ \\
\hline L-Serine & - & - & & - & - & - & & + & + & \\
\hline L-Threonine & - & - & & - & - & - & & 7 & + & $(-): 68,73,76$ \\
\hline L-Leucine & - & - & & + & 1 & - & $(+): 188$ & - & - & \\
\hline L-Isoleucine & - & - & & - & 2 & - & $(+): 162,188$ & - & - & \\
\hline L-Valine & 2 & - & $(+): 148,153$ & - & - & - & & - & - & \\
\hline L-Aspartate & - & - & & + & - & - & & + & + & \\
\hline L-Glutamate & (9) & + & $(-): 149,150$ & + & 16 & + & $\begin{array}{l}(+): 161-167 \\
178-180,184- \\
186,189,191 \\
192\end{array}$ & + & + & \\
\hline L-Arginine & 2 & - & $(+): 148,149$ & - & - & - & & + & + & \\
\hline L-Ornithine & $(10)$ & + & $(-): 150$ & - & - & - & & + & + & \\
\hline $\begin{array}{l}\gamma \text {-Aminobutyr- } \\
\text { ate }\end{array}$ & 3 & + & $(+): 145,146,151$ & - & - & - & & + & + & \\
\hline
\end{tabular}




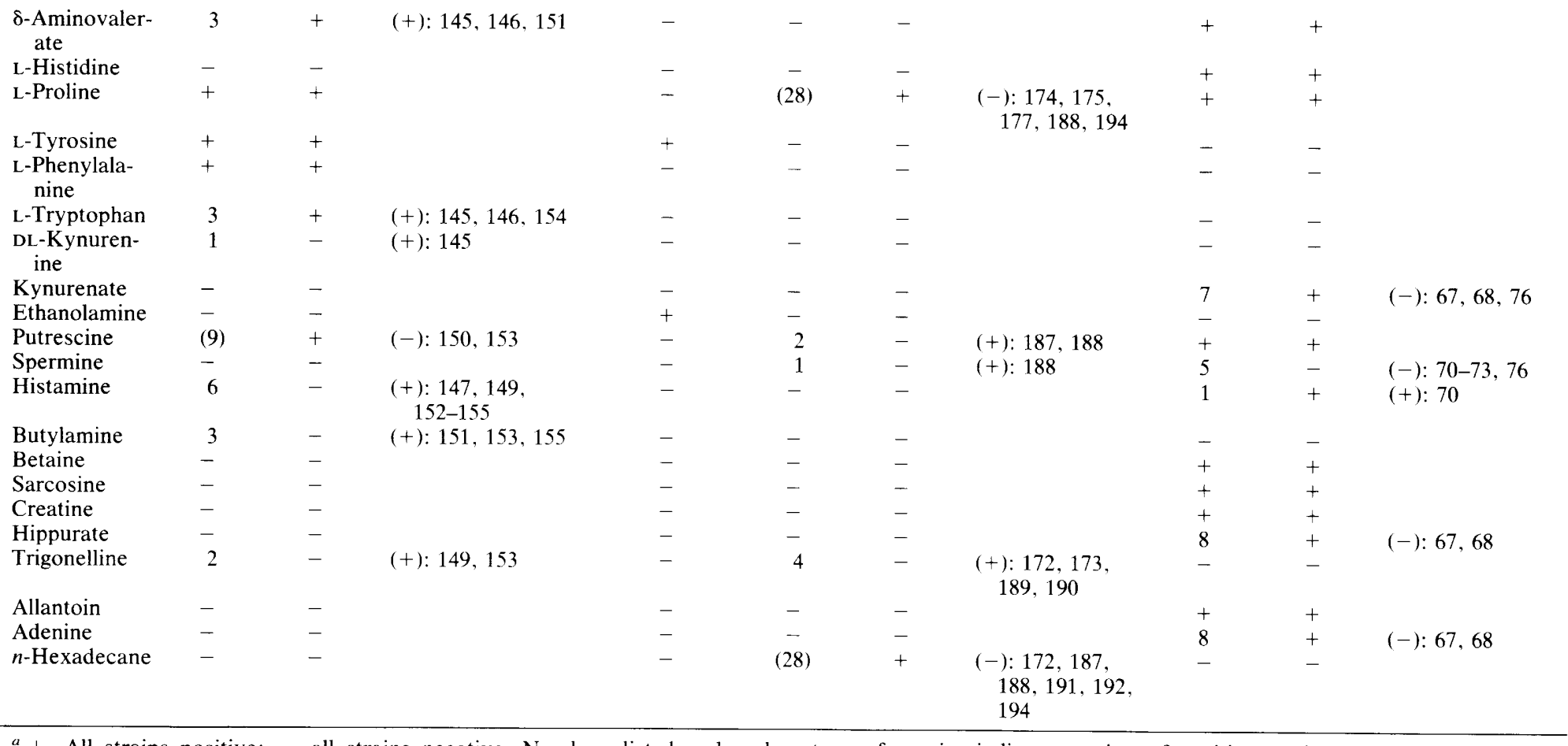

+, All strains positive; -, all strains negative. Numbers listed under phenotype of species indicate number of positive strains. Numbers in parentheses represent $80 \%$ or more of the strains.

${ }^{b}$ Numerical designation of strains: P. stanieri, 145 to $155 ; P$. nautica, 161 to $194 ; P$. doudoroffii, 67 to 76

${ }^{c}$ Numbers in boldface indicate that the flagella are present at both poles.

${ }^{d} m$, meta cleavage; $o$, ortho cleavage. 
p-aminobenzoate, methylamine, benzylamine, tryptamine, 2-amylamine, pentylamine, pantothenate, acetamide, nicotinate, nicotinamide, guanine, cytosine, thymine, and uracil. Traits present in only some of the strains of each species of marine Pseudomonas are presented in Table 1.

\section{DISCUSSION}

The genus Pseudomonas is currently defined as consisting of gram-negative, obligately respiratory, rod-shaped, polarly flagellated organisms which have $\mathrm{G}+\mathrm{C}$ contents in their DNAs of 58 to $70 \mathrm{~mol} \%$ (12). The genus is heterogeneous: studies of ribosomal ribonucleic acid (rRNA) sequence similarity have indicated that its constituent species can be assigned to five distinct evolutionary lineages, some of which have higher affinities to other bacterial genera than to the remaining species of Pseudomonas (9-11, 13, 15, 18, 19, 21). The evolutionary branch which includes $P$. aeruginosa, the type species of the genus, has been designated rRNA homology group I by Palleroni et al. (15). The common origin of the organisms in this rRNA homology group has been corroborated by a number of independent attributes, namely, glutamine synthetase sequence similarities (2) as well as the distinctive patterns of regulation of key enzymes in the biosynthesis of aromatic amino acids $(7,22)$ and the enzyme aspartokinase (8). $P$. nautica, $P$. doudoroffii, " $P$. perfectomarinus," and group G-1 are four marine species which share many of these distinctive properties with species of rRNA homology group I and are, therefore, part of this lineage (1. 7, 22; DeLong et al., in press). Since the sole reason for not placing group G-1 into Pseudomonas has been the slightly lower $\mathrm{G}+\mathrm{C}$ content of its DNA (55 to $57 \mathrm{~mol} \%$ ) (3) relative to that accepted as the lower limit for the genus Pseudomonas, there is no longer a reason to exclude this species now that a relationship between these organisms has been demonstrated. Consequently, we propose to name group $\mathrm{G}-1 P$. stanieri sp. nov.

Liu et al. have performed extensive studies on the physiological mechanism of denitrification in the single marine isolate of " $P$. perfectomarinus" (14). According to the phenotype and the Fe-containing superoxide dismutase and glutamine synthetase sequences of this strain, it does represent a distinct species (3; DeLong et al., in press). Since this name has not been placed on the Approved List of Bacterial Names, we propose its revival under the corrected designation $P$. perfectomarina sp. nov., nom. rev.

The following is a description of $P$. stanieri and $P$. perfectomarina as well as $P$. nautica and $P$. doudoroffii. A previous publication (3) did not include the phenotypic properties of the type strain or the remaining strains of the latter two species. Light and electron micrographs showing the general cell morphology and flagellation of strains representative of $P$. doudoroffi $i$ and $P$. nautica have been previously published $(3,6)$. Figure $1 \mathrm{~A}$ is an electron micrograph showing the morphology and flagellation of $P$. stanieri; Fig. $1 \mathrm{~B}$ shows the morphology of $P$. perfectomarina, which is nonmotile due to lack of flagella.

Pseudomonas stanieri sp. nov. (stan'ier.i M. L. gen. n. stanieri; named after R. Y. Stanier, a Canadian microbiologist who made extensive contributions to general microbiology and, in particular, to Pseudomonas). Straight rods, 0.6 to $0.8 \mu \mathrm{m}$ in width and 1.3 to $2.2 \mu \mathrm{m}$ in length; motile by a single flagellum at one pole (Fig. 1A). Accumulate poly- $\beta$-hydroxybutyrate as an intracellular reserve product. Utilize 28 to 42 organic compounds including fatty acids, tricarboxylic acid cycle intermediates, alcohols, aromatic compounds, and amino acids. Do not

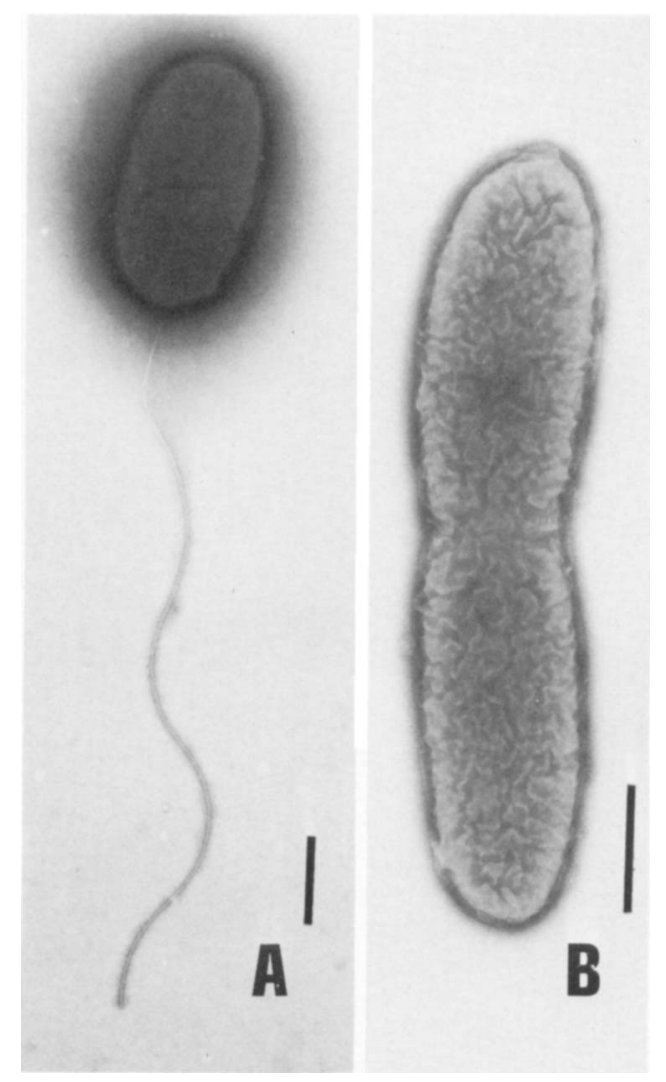

FIG. 1. Electron micrographs of (A) $P$. stanieri $146^{\mathrm{T}}(\times 18,000)$ and $(\mathrm{B}) P$. perfectomarina $218^{\mathrm{T}}$ $(\times 27,000)$ in exponential phase of growth in liquid media. Bar represent $0.5 \mu \mathrm{m}$. 
utilize carbohydrates or produce an extracellular amylase, gelatinase, lipase, or chitinase. Aromatic compounds, if utilized, are degraded by means of the $\alpha$-keto acid pathway as indicated by the $m$-cleavage of diphenolic intermediates (20). The pattern of regulation of aspartokinase activity resembles that of Pseudomonas rRNA homology group I (1). The mol\% $\mathrm{G}+\mathrm{C}$ content in the DNA is 55 to 57.

Type strain: 146 (ATCC 27130).

Pseudomonas perfectomarina sp. nov., nom. rev. (per.fec.to.ma.ri'na L. fem. partic. perfecto perfect, complete; L. fem. adj. marina of the sea, marine; perfectomarina M. L. fem. adj. completely marine). Straight or slightly curved rods 0.5 to $0.7 \mu \mathrm{m}$ in width and 1.1 to $1.9 \mu \mathrm{m}$ in length; nonmotile (Fig. 1B). Vigorous denitrifier. Utilizes 45 organic compounds which include D-glucose and maltose, but no other pentose, hexose, or disaccharide; utilizes fatty acids, tricarboxylic acid cycle intermediates, alcohols, and amino acids. Does not utilize aromatic compounds. The mol\% $\mathrm{G}+\mathrm{C}$ content in the DNA is 62.

Type strain: 218 (ATCC 14405).

Pseudomonas nautica. Straight rods, 0.3 to $0.5 \mu \mathrm{m}$ in width and 1.5 to $3.0 \mu \mathrm{m}$ in length. Motile by single flagellum at one pole. Cells in early exponential phase of growth may have one to three lateral flagella of a shorter wavelength than that of the polar flagellum. Vigorous denitrifiers; produce an extracellular lipase. Utilize 17 to 29 organic compounds including fatty acids, dicarboxylic acids, and alcohols. Do not utilize carbohydrates. Benzoate, if utilized, is degraded via the $\beta$-ketoadipate pathway as is indicated by the $o$-cleavage of catechol (20). The pattern of regulation of aspartokinase activity in this species is similar to that of rRNA homology group I (1). The mol\% $\mathrm{G}+\mathrm{C}$ content in the DNA is 57 to 62 .

Type strain: 179 (ATCC 27132).

Pseudomonas doudroffii. Straight rods, 0.7 to $1.2 \mu \mathrm{m}$ in width and 2.0 to $2.5 \mu \mathrm{m}$ in length; motile by one to three flagella at each pole. Accumulate poly- $\beta$-hydroxybutyrate. Utilize 34 to 42 carbon compounds, including D-fructose (some strains also utilize D-ribose) but no other pentose, hexose, or disaccharide; utilize tricarboxylic acid cycle intermediates, aromatic compounds, amino acids, and amines. Aromatic compounds are degraded via the $\beta$-ketoadipate pathway as indicated by the o-cleavage of diphenolic intermediates (20). Although by Fecontaining superoxide dismutase and glutamine synthetase sequence similarity $P$. doudoroffii appears to be related to Pseudomonas species of rRNA homology group I, it differs by its distinctive pattern of aspartokinase regulation (1) and the presence of a constitutive 6-phosphofructo-

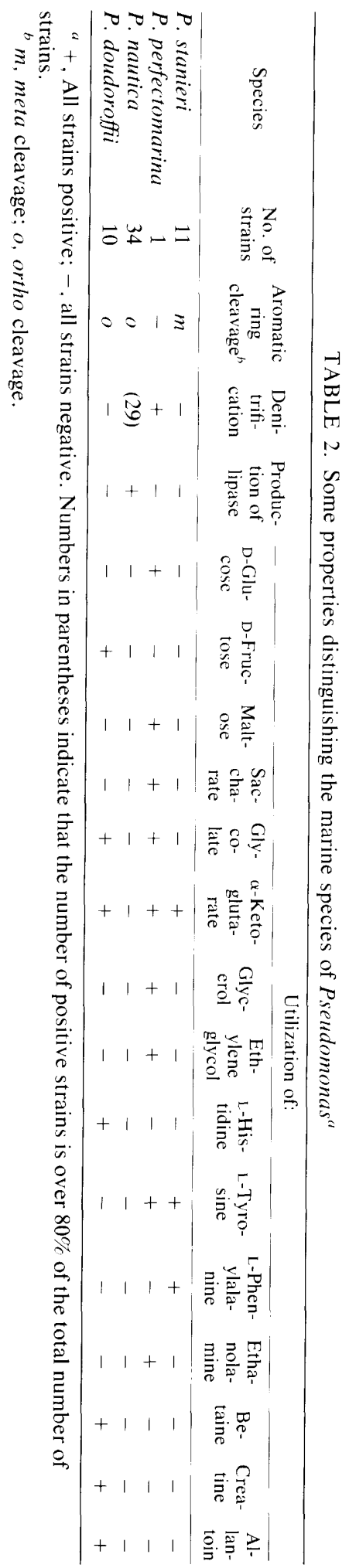


TABLE 3. Properties distinguishing the marine Pseadomonas from other marine, obligately aerobic, polarly flagellated rods ${ }^{\prime \prime}$

\begin{tabular}{|c|c|c|c|c|c|c|}
\hline \multirow{2}{*}{ Species } & \multirow{2}{*}{ Denitrification } & \multirow{2}{*}{$\begin{array}{c}\text { Production of } \\
\text { Gelatinase }\end{array}$} & \multicolumn{3}{|c|}{ Utilization of: } & \multirow[b]{2}{*}{ Mannitol } \\
\hline & & & D-Glucose & D-Fructose & Gluconate & \\
\hline P. stanieri & - & - & - & - & - & - \\
\hline$P$. perfectomarina & + & - & + & - & - & - \\
\hline$P$. nautica & $(+)$ & $(-)$ & - & - & - & - \\
\hline P. doudoroffii & - & - & - & + & - & - \\
\hline Deleya marina & - & - & + & + & + & + \\
\hline Alteromonas spp. & - & + & $(+)^{c}$ & & & \\
\hline
\end{tabular}

${ }^{a}+$, All strains positive; $(+)$, over $80 \%$ of the strains are positive; - , all strains negative; $(-)$, less than $5 \%$ of the strains are positive.

${ }^{b}$ A. macleodii, A. haloplanktis, A. espejiana, A. undina, A. rubra, A. luteoviolacea, A. citrea, and A. aurantia.

"A. hanedai, a bioluminescent species, contains strains unable to utilize D-glucose.

kinase $(4,15)$. The mol\% $\mathrm{G}+\mathrm{C}$ content in the DNA is 58 to $60(\mathrm{Bd})$.

Type strain: 70 (ATCC 27123).

The properties which distinguish species of marine Pseudomonas from one another are presented in Table 2. A number of other polarly flagellated, rod-shaped, marine species belonging to genera other than Pseudomonas have been described. Nine such species have been placed into the genus Alteromonas $(5 ; \mathrm{P}$. Baumann, M. Gauthier, and L. Baumann, Bergey's Manual of Systematic Bacteriology, 9th ed.. 1983 , in press) and one into the newly proposed genus Deleya (4) which consists primarily of peritrichous organisms. The properties useful in distinguishing the marine Pseudomonas from these organisms are presented in Table 3. The marine Pseudomonas differ from terrestrial species of the genus in requiring over $75 \mathrm{mM} \mathrm{NaCl}$ for optimal growth rate and cell yield.

\section{ACKNOWLEDGMENTS}

We thank J. G. Holt for help with nomenclature. This study was supported by National Science Foundation grant no. DEB-8205938 as well as by the Aquaculture Program, University of California, Agricultural Experiment Station.

\section{LITERATURE CITED}

1. Baumann, L., and P. Baumann. 1974. Regulation of aspartokinase activity in non-fermentative, marine eubacteria. Arch. Microbiol. 95:1-18.

2. Baumann, L., and P. Baumann. 1978. Studies of relationship among terrestrial Pseudomonas, Alcaligenes, and enterobacteria by an immunological comparison of glutamine synthetase. Arch. Microbiol. 119:25-30.

3. Baumann, L., P. Baumann, M. Mandel, and R. D. Allen. 1972. Taxonomy of aerobic marine eubacteria. J. Bacteriol. 110:402-429.

4. Baumann, L., R. D. Bowditch, and P. Baumann. 1983. Description of Deleya gen. nov. created to accommodate the marine species Alcaligenes aestus, A. pacificus, A. cupidus, A. venustus, and Pseudomonas marina. Int. J. Syst. Bacteriol. 33:793-802.

5. Baumann, P., and L. Baumann. 1975. Catabolism of Dfructose and D-ribose by Pseudomonas doudoroffii $\mathrm{I}$
Physiological studies and mutant analysis. Arch. Microbiol. 105:225-240.

6. Baumann, P., and L. Baumann. 1981. The marine gramnegative eubacteria: genera Photobacterium, Beneckea, Alteromonas, Pseudomonas, and Alcaligenes, p. 13021331. In M. P. Starr, H. Stolp, H. G. Trüper, A. Balows, and H. G. Schlegel (ed.), The prokaryotes. SpringerVerlag, Berlin.

7. Byng, G. S., R. J. Whitaker, R. L. Gherna, and R. A. Jensen. 1980. Variable enzymological patterning in tyrosine biosynthesis as a means of determining natural relatedness among Pseadomonadaceae. J. Bacteriol. 144:247257.

8. Cohen, G. N., R. Y. Stanier, and G. Le Bras. 1969. Regulation of the biosynthesis of amino acids of the aspartate family in coliform bacteria and pseudomonads. J. Bacteriol. 99:791-801

9. De Ley, J., P. Segers and M. Gillis. 1978. Intra- and intergeneric similarities of Chromobacterium and Janthiobacterium ribosomal ribonucleic acid cistrons. Int. J. Syst. Bacteriol. 28:154-168.

10. De Smedt, J., M. Bauwens, R. Tytgat, and J. De Ley. 1980. Intra- and intergeneric similarities of ribosomal ribonucleic acid cistrons of free-living, nitrogen-fixing bacteria. Int. J. Syst. Bacteriol. 30:106-122.

11. De Smedt, J., and J. De Ley. 1977. Intra- and intergeneric similarities of Agrobacterium ribosomal ribonucleic acid cistrons. Int. J. Syst. Bacteriol. 27:222-240.

12. Doudoroff, M., and N. J. Palleroni. 1974. Genus Pseudomonas, p. 217-243. In R. E. Buchanan and N. E. Gibbons (ed.). Bergey's manual of determinative bacteriology, 8th ed. The Williams \& Wilkins Co., Baltimore.

13. Fox, G. E., E. Stackebrandt, R. B. Hespell, J. Gibson, J. Maniloff, T. A. Dyer, R. S. Wolfe, W. E. Balch, R. S. Tanner, L. J. Magrum, L. B. Zablen, R. Blakemore, R. Gupta, L. Bonen, B. J. Lewis, D. A. Stahl, K. R. Luehrsen, K. N. Chen, and C. R. Woese. 1980. The phylogeny of prokaryotes. Science 209:457-463.

14. Liu, M.-C., W. J. Payne, H. D. Peck, Jr., and J. Le Gall. 1983. Comparison of cytochromes from anaerobically and aerobically grown cells of Pseadomonas perfectomarinus. J. Bacteriol. 154:278-286.

15. Palleroni, N. J., R. Kunisawa, B. Contopoulou, and M. Doudoroff. 1973. Nucleic acid homologies in the genus Pseudomonas. Int. J. Syst. Bacteriol. 23:333-339.

16. Sawyer, M. H., P. Baumann, L. Baumann, S. M. Berman, and J. L. Cánovas. 1977. Pathways of D-fructose catabolism in species of Pseudomonas. Arch. Microbiol. 112:4955.

17. Skerman, V. B. D., V. McGowan, and P. H. A. Sneath. 1980. Approved list of bacterial names. Int. J. Syst. Bacteriol. 30:225-420. 
18. Stackebrandt, E., and C. R. Woese. 1981. The evolution of prokaryotes. p. 1-32. In M. J. Carlile, J. F. Collins, and B. E. B. Moseley (ed.), Molecular and cellular aspects of microbial evolution. Cambridge University Press, London.

19. Stanier, R. Y. 1976. Réflexions sur la taxonomie des Pseudomonas. Bull. Inst. Pasteur (Paris) 74:255-270.

20. Stanier, R. Y., N. J. Palleroni, and M. Doudoroff. 1966. The aerobic pseudomonads: a taxonomic study. J. Gen. Microbiol. 43:159-271.
21. Swings, J., P. De Vos, M. Van den Mooter, and J. De Ley. 1983. Transfer of Pseudomonas maltophilia Hugh 1981 to the genus Xanthomonas as Xanthomonas maltophilia (Hugh 1981) comb. nov. Int. J. Syst. Bacteriol. 33:409413.

22. Whitaker, R. J., G. S. Byng, R. L. Gherna, and R. A. Jensen. 1981. Comparative allostery of 3-deoxy-D-arabino-heptulosonate 7 -phosphate synthetase as an indicator of taxonomic relatedness in pseudomonad genera. J. Bacteriol. 145:752-759. 